\title{
Erasmus exchange in the field of family medicine in Slovenia
}

\author{
Danica Rotar-Pavlič
}

University of Ljubljana, Medical Faculty Department of Family Medicine Ljubljana, Slovenia

\author{
Corresponding author: \\ Danica Rotar-Pavlič \\ University of Ljubljana \\ Medical Faculty \\ Department of Family Medicine \\ Poljanski nasip 58 \\ 1000 Ljubljana \\ Slovenia \\ danica.rotar@guest.arnes.si \\ Tel.: + 38612572424 \\ Fax: + 38614386910
}

Received: 20 December 2011

Accepted: 28 February 2012

Copyright (c) 2012 by

Academy of Sciences and Arts

of Bosnia and Herzegovina.

E-mail for permission to publish:

amabih@anubih.ba

\begin{abstract}
Objective. The purpose of this paper is to analyze the Erasmus exchange of students at the University of Ljubljana, Department of family medicine in the period from 2005 to 2010. The beginnings of an Erasmus exchange in the field of family medicine in Europe are described. Ljubljana Medical School has currently 60 bilateral agreements with universities or medical faculties in the EU and EFTA countries. Materials and methods. We collected data of all students who come from the foreign faculties to the Department of family medicine and those from Slovenia who went to study abroad. In addition to basic descriptive statistics, we used the elements of qualitative analysis, where we reviewed the reports of the Slovenian Erasmus students, who went on exchange in the field of family medicine. Results. Department of family medicine cooperated with 14 foreign medical schools since 2005. 42 Slovenian students went on academic exchange in the field of family medicine. 21 foreign students came to Department of family medicine in Ljubljana. Female students were more frequent in exchange compared with male students. The largest proportion of students went abroad in 2009. Most foreign students visited Department of Family medicine in Ljubljana in 2011. Reports of students show that they learned a lot. Students were able to compare the organization of health care in a foreign country and Slovenian health care system. Conclusion. Erasmus exchange has proven to be an important addition to the existing educational system. Students are acquainted with the progress of health care in Europe in this way. They are able to compare the benefits and disadvantages of foreign health care systems with home health care organization.
\end{abstract}

Key words: Undergraduate education, Erasmus exchange, Student, Family medicine.

\section{Introduction}

Family medicine in Europe has a growing influence; this could be seen in the area of education as well. Most medical schools in Europe restructured curriculum few decades ago (1). The reform had to happen, because health system (medical education included) should follow the health needs of the population. Only by the way of reforms the health system can better address health issues in the community. Since family practitioners are front line clinicians, they were included in health sector reforms. Family 
practitioners work in the community where their patients live and provide for them individual care over longer periods of time. As a consequence, family medicine as a clinical field has been integrated in most medical schools, with family physicians making a unique contribution to the teaching (2).

Integral part of family physician contribution to medical curriculum is a practice attachment, giving the opportunity for students to experience clinical reality in family medicine setting. European Academy of Teachers in General Practice / Family Medicine (EURACT) had important role in reforms in medical education (3). Based on these experiences, a European student exchange has been developed in 1992 under the EU Erasmus program (2).

The main objective of the Erasmus student exchange is organization of student exchange under study periods, which means that students can complete part of their regular academic study or practice in one of the institutions of the Member States of the European Union (EU) and the European Free Trade Association (EFTA). Medical Faculty of University of Ljubljana is included in the network of European medical faculties ECTS-MA (4) since 2008. It currently has 60 bilateral agreements with universities or medical faculties in the EU and EFTA countries. If a student wishes to pursue academic requirements at institutions with which the Faculty has signed contracts, the latter can further be concluded. The contracts specify the number of students and duration (number of months) abroad. Based on these contracts each year a tender is undertaken in which terms and method of selection of candidates specified. Selected students from going abroad, together with the faculty program coordinators and program coordinators at the partner institutions shall draw up a study plan, obtain the agreement of the heads of institutes and chairs of objects that they intend to perform abroad. The study period is a time-limited and lasts for studying at a partner institution for at least three months to twelve months (4).

The subgroup of coordinators, professors and teachers in the field of Family medicine was established in 2004, founded by professor Chris van Weel. University of Nijmegen was the first that came to exchange of students in the field of family medicine. The first students from Nijmegen were engaged in learning activities at the Universities of Southampton and Ghent (2). Department of Family medicine of the University of Ljubljana started to participate in this group in 2005.

The purpose of this paper is to analyze the Erasmus exchange of students at the University of Ljubljana, Department of family medicine in the period from 2005 to 2010.

\section{Methods}

In the analysis of student exchange program we used parameters of descriptive statistics. We collected data on students of the Faculty of Medicine of Ljubljana who went to study in foreign universities. We also analyzed data on students who come from foreign universities to study at the Medical Faculty of Ljubljana. We analyzed data from the beginning of the Erasmus exchange, which is from 2005 onwards. The analysis did not include students who came to Ljubljana in summer practice, and those Slovenian students who went abroad to do the summer practice in their holiday period. We also reviewed reports, which were written by the exchange students in the period 2009/2010 (5).

\section{Results}

Department of Family Medicine cooperated with 14 foreign medical schools since 2005. They are as follows: Imperial college of London, Radboud University Nijmegen, Medical University of Vienna, University 
Strasbourg, Ludwig Maxmilians Universität München, Faculty of Medicine and Health Sciences, Ghent University, Prvi Medicinski Fakulteti Karlove Univerze v Pragi, Medicinske fakultete Univerze Masaryk, Brno, University Pais Vasco Santiago de compostella Spain, Masaryk University Latvia, Medical University of Warsaw, Univeristy Madrid, University Johannes Gutenberg Mainz, Sahlgrenska Academy at the University of Gothenburg.

Overall, 42 students went to study abroad: 13 male and 29 female students. 21 foreign students (16 female students and 5 male students) came to study family medicine at the Department of Family medicine in Ljubljana. The overview of the Erasmus exchange is shown in Table 1.

Table 1 Out coming and incoming Erasmus students at the Department of family medicine, University of Ljubljana

\begin{tabular}{cll}
\hline Year & Out-coming students & Incoming students \\
\hline 2005 & 2 & 1 \\
2006 & 3 & 1 \\
2007 & 9 & 2 \\
2008 & 4 & 6 \\
2009 & 13 & 4 \\
2010 & 7 & 0 \\
2011 & 4 & 7 \\
\hline Total & 42 & 21 \\
\hline
\end{tabular}

The largest proportion of students went abroad in 2009. Most foreign students visited Department of Family medicine in Ljubljana in 2011. Most of Slovenian students in the field of family medicine went on exchange to Imperial College of London (13 students), followed by the Radboud University Nijmegen (7 students), and Sahlgrenska Academy at the University of Gothenburg in third place. Of the foreign students who come to study at the Department of Family Medicine of Ljubljana, the largest proportion was the Dutch students (9 students).
Female students were more frequent in exchange compared with male students.

Below we present two examples of student exchanges. The first example clearly describes how the clinical exchange took place, in another case; it is described how a student study carried out a survey in the so-called "research elective" (5).

"I performed exercises in family medicine at separate locations with different doctors. I started in a suburb called IllkirchGraffenstaden. This place is bordering rural areas of Alsace, which was opposite to the place in the center of Strasbourg, where the second clinic was located. The work was divided into morning and afternoon from Monday to Friday and sometimes on Saturday. It was comprised of both ambulatory work and home visits. General practitioners tend to have a clinic next to each other in groups of two or three, which allows them to consult each other and make the most economical organization of the work schedule so someone is always present even on Saturdays. Health care system is organized somewhat differently than in Slovenia, because patients pay for the examination then get their money refunded in a few days of $90-$ s per cent. This applies only to the Alsace-Lorraine, which is legally and culturally a bit separated from the rest of France. Elsewhere in France the figure of reimbursement is lower, ranging around 70\%. Regarding casuistic of diseases there is not essential difference compared with Slovenian situation. The range of diseases is really wide, i.e. infectious diseases, dermatological and orthopedic complaints, neurological disorders, psychiatric diseases, prevention and vaccination. My mentor was taking care of drug addicts in addition. The age of patients varied from childhood to old age. Elderly patients were visited at their homes. Most of them had problems with movement, but some were in the terminal stage of disease and needed palliative care treatment. I 
was included in the whole process of care, from taking a history through the status and the therapy. My mentor guided me and we discussed about everything" (VS, male student).

"On the call of the Erasmus program I first heard about the possibility of pursuing an Erasmus study at Imperial College of London. My work was in the majority of research in nature and was held at the e-Health Unit, which operates on the Department of Primary Care and Public Health at Charing Cross. My mentor chose the field of computer-assisted detection for taking history of domestic violence for my research project. Much research is done in this field and most of it shows that patients are more honest when they talk about sensitive information (drinking alcohol, sexual history, family violence) if the "computer" asks them compared with the consultation at the doctor's office. Mentor was a good supporter in research work; he helped me with advices and encouragement. There were several young researchers who have worked for systematic literature reviews Cochran database (Cochrane Review systematic) at the Department. Every Wednesday I attended a lecture at the department. Once a week I went to the clinic dr. Bootona Paul, professor of general medicine at Imperial. I learnt a lot about the organization of general practice in England and about working stiles of GP's. I also attended several open lectures, which were organized at the Faculty of Medicine and the exercises in communication skills, which were held for students at the Department of Primary Care and Public Health. I took advantage of free time for socializing with students who come from different parts of the world". (MS, female student).

Reports of students show that they learned a lot. Students were able to compare the organization of health care in a foreign country and Slovenian health care system. Reports show students that are abroad ac- quainted with the introduction of innovations in family medicine, such as the implementation of e-health platform. We also know that family medicine in some countries carry out procedures like proctologic interventions, dermatoskopic examinations and many other procedures.

\section{Discussion}

The Ljubljana medical school introduced the program of family medicine more than 15 years ago. The program is conducted in seven weeks blocks, where work with tutors in place is combined with structured teaching at the department (6). The department of family medicine joined to international Erasmus exchange programme in 2005. To date, there has been no analysis of how many students went on exchange abroad, and how many of them came to study in Slovenia, so this article provides the first overview of the exchange in a period of seven years.

We estimate that 14 medical schools with which Department of family medicine cooperates is a big and important issue. It is also important to work with faculties from across Europe, allowing teachers to know the faculty organization and content of the other faculties, and compare the content of the family medicine field on the home university. The total number of exchanges is valued as large and important, because we know that for every foreign student a tutor has to organize individual classes and to conduct the training in English. This certainly presents for a tutor additional work and burden.

In addition to basic knowledge and skills that students receive at home faculty Erasmus exchange program gives opportunity to learn about organization of primary care in a foreign country and to make a comparison of two different health systems. They value the financing of primary health care at home and abroad. They compare the treat- 
ment options of patients in the foreign and domestic environments. They learn to identify where are the strengths and weaknesses of the primary health care. Since we didn't find the other possible analysis and comparison of student exchange, we will continue with collecting data and prepare additional research in the future. Living and studying medicine in a new environment exposes students to new clinical methods and thinking as well as equipping them with invaluable linguistic and interpersonal skills. Setting up such an exchange requires initiative and perseverance, but the rewards are immense and life-long (7).

\section{Conclusion}

The results of our study indicate that student exchange represents an important added value to the existing educational system. Department of family medicine in Ljubljana has been successfully cooperating with many foreign universities. A large number of students, who decided to study abroad, from the year 2005 onwards, show that we fulfilled the mission of student exchange and that this way of organization of teaching is useful and interesting.

Acknowledgment: We thank all students who have gathered the courage to get involved in an Erasmus exchange. Special thanks doc. dr. Tomaž Marš, the main coordinator of the Erasmus exchange at the Medical Faculty in Ljubljana. We also thank the head of the Department of Family Medicine Prof. Igor Švab, who supports the Erasmus exchange within the department of family medicine

Conflict of interest: The author declare that she has no conflict of interest. This article was not sponsored by any external organisation.

\section{References}

1. General Medical Council. Tomorrow's doctors. London, 2003. Available from: http://www.gmcuk.org/TomorrowsDoctors_2003.pdf_39262074. pdf (accessed 9.4. 2012).

2. Van Weel C, Mattsson B, Freeman GK, de Meyere M, von Fragstein M. General Practice based Teaching Exchanges in Europe. Experiences from EU Socrates Programme 'Primary Health Care'. Eur J Gen Pract. 2005;11(3):122-6.

3. Council of European Academy of Teachers in General Practice. The EURACT educational agenda of general practice/family medicine. Greece, 2005. http://www.euract.eu/official-documents/ finish/3-official-documents/93-euract-educational-agenda (accessed 9.4.2012).

4. Predstavitev programa Erasmus na Medicinski fakulteti UL. Available from: http://www.mf.unilj.si/dokumenti/f821e9c4028302d1b6258d99e2ebaac3.pdf (accessed 9.4.2012).

5. Študijska poročila Erasmus študentov medicinske fakultete Univerze v Ljubljani za študijsko leto 2009/2010. Ljubljana, 2010. Available from: http:// www.mf.uni-lj.si/dokumenti/2792f82ac7a2a481e c750f078922fc3e.pdf (accessed 9.4. 2012)

6. Švab I, Petek-Šter M. Long-term evaluation of undergraduate family medicine curriculum in Slovenia. BIBLID. 2008; 5-6:274-279.

7. Erasmus - Establishing exchanges of undergraduate medical students in the European Union. Available from: http://www.almamata.net/news/careers/ education/features/erasmus (accessed 9.4.2012). 